\title{
Asuransi Kecelakaan Kendaraan Bermotor Roda Dua Sebagai Moda Transportasi Umum Berbasis Online
}

\author{
Hezron Sabar Rotua Tinambunan, Bagas Waskito, \\ Muhammad Bayu Rizhaldi, dan Athia Fadzri K.R. Uno \\ Fakultas Ilmu Sosial dan Hukum Universitas Negeri Surabaya \\ Jln. Ketintang No.i8, Ketintang, Kec. Gayungan, Kota Surabaya, Jawa Timur \\ hezrontinambunan@unesa.ac.id, bagaswaskito30699@gmail.com, \\ bayualdi5@gmail.com, tiarauno9@gmail.com
}

Received: 1 oktober 2019; Accepted: 9 Januari 2020; Published: 17 Februari 2020

DOI: 10.20885/iustum.vol26.iss3.art10

\begin{abstract}
This research focuses on two discussions, first, to analyze the arrangement of accident insurance for two-wheeled motor vehicles as a mode of online-based public transportation in Law No. 22 of 2009 on Traffic and Road Transportation (LLAJ Law). Second, to analyze the mechanism of insurance fulfillment for losses arising from the accidents of two-wheeled motor vehicle as an online-based public transportation mode. This research is a normative legal study. It concludes that first, PT. Jasa Raharja cannot provide protection for people who take the two-wheeled motor vehicles as a means of public transportation, because such vehicles are not included as the public motor vehicles according to the LLAJ Law. However, the providers of public transportation services with two-wheeled motor vehicles as the means of transportation can partner-up with the private insurance companies, or they can provide their own insurance system. Second, if the insurance is not provided, then public transportation service providers can be deemed as default based on the terms and conditions that have been made. Improvements to the LLAJ Law are necessary especially regarding the unclear provisions relating to the accountability of public transport companies and technology-based application provider companies.
\end{abstract}

Keywords: Insurance; accident; legal protection; two-wheeled online transportation

\section{Abstrak}

\begin{abstract}
Penelitian ini fokus pada dua pembahasan, pertama, menganalisis pengaturan asuransi kecelakaan bagi kendaraan bermotor roda dua sebagai moda transportasi umum berbasis online ditinjau dari UU Nomor 22 Tahun 2009 tentang Lalu Lintas dan Angkutan Jalan. Kedua, menganalisis mekanisme pemenuhan asuransi atas kerugian yang timbul dari kecelakaan kendaraan bermotor roda dua sebagai moda transportasi umum berbasis online. Penelitian ini merupakan jenis penelitian hukum normatif. Penelitian ini menyimpulkan bahwa pertama, produk asuransi sosial PT. Jasa Raharja tidak dapat melindungi masyarakat yang menggunakan kendaraan bermotor roda dua sebagai sarana angkutan umum, karena kendaraan bermotor roda dua tidak termasuk kendaraan bermotor umum menurut UU LLAJ. Namun, penyedia jasa transportasi umum dengan jenis kendaraan bermotor roda dua sebagai sarana angkutannya, dapat bermitra dengan perusahaan asuransi swasta, atau menyediakan sistem asuransi sendiri. Kedua, apabila asuransi tidak diberikan, maka penyedia jasa transportasi umum (online) dapat dikategorikan wanprestasi berdasarkan syarat dan ketentuan yang telah dibuatnya. Perlu perbaikan terhadap UU LLAJ mengenai ketentuan-ketentuan yang tidak jelas, berkaitan dengan pertanggungjawaban perusahaan angkutan umum maupun perusahaan penyedia aplikasi yang berbasis teknologi.
\end{abstract}

Kata-kata Kunci : Asuransi; kecelakaan lalu lintas; perlindungan hukum; transportasi online roda dua 


\section{Pendahuluan}

Transportasi merupakan suatu sistem yang terdiri dari sarana dan prasarana, didukung tata laksana dan sumber daya manusia yang membentuk jaringan pelayanan fungsi sebagai penggerak, pendorong, dan penunjang pembangunan. ${ }^{1}$ Keberhasilan pembangunan sangat bergantung pada sektor transportasi, yang berfungsi sebagai lokomotif ekonomi. Diperlukan pengaturan bagi sarana transportasi agar dalam pengoperasiannya sesuai dengan peraturan perundangundangan di Indonesia. Tujuan dari pengaturan sektor transportasi jalan ini adalah menghasilkan jasa transportasi yang handal, berkemampuan tinggi dan diselenggarakan secara terpadu, tertib, lancar, aman, nyaman dan efisien dalam menunjang sekaligus menggerakkan dinamika perekonomian. ${ }^{2}$

Belum jelasnya pihak yang menanggung kerugian ekonomi dari kecelakaan lalu lintas jalan menjadi permasalahan tersendiri dalam sektor transportasi. Sebagian besar beban perawatan jangka panjang pasti jatuh pada keluarga dari korban kecelakaan, dan korban juga dapat kehilangan pekerjaannya. Bahkan, keluarga korban kecelakaan akan kehilangan sumber pendapatan ketika sumber pencaharian utamanya meninggal dunia. Kecelakaan lalu lintas jalan merupakan bentuk eksternalitas negatif yang mengakibatkan korban meninggal, terluka, atau mengalami kerugian material.

Ojek sepeda motor telah menjadi alternatif angkutan bagi sebagian masyarakat karena fleksibel, bisa menjangkau tempat yang tidak dapat dilalui angkutan umum seperti angkutan kota, bus, atau jenis angkutan umum beroda empat lain. Secara de facto, keberadaan ojek sepeda motor dianggap sangat membantu masyarakat dalam memecahkan kendala terhadap tersedianya angkutan umum sebagai angkutan alternatif, namun secara de jure, keberadaan ojek sepeda motor dianggap bermasalah dalam hal legalitas. Hal ini karena secara normatif penggunaan sepeda motor sebagai transportasi umum tidak memiliki landasan hukum, utamanya pengaturan mengenai asuransi kecelakaan yang ditimbulkan oleh ojek sepeda motor. ${ }^{3}$

\footnotetext{
${ }^{1}$ Warpani, P. Suwardjoko, Merencanakan Sistem Perangkutan, Penerbit ITB, Bandung, 1990, hlm. 20.

2 Abdulnakir Muhammad, Hukum Pengangkutan Niaga, Citra Aditya Bakti, Bandung, 1998, hlm. 7.

${ }^{3}$ Dian Mandayani Ananda Nasution, "Tinjauan Hukum Terhadap Layanan Transaksi Dan Transportasi Berbasis Aplikasi Online”, RESAM, Vol.4, No. 1, April, 2018, hlm. 20.
} 
Menurut Menteri Perhubungan, Budi Karya Sumadi menyebutkan bahwa angka kecelekaan sepeda motor di Indonesia sangat besar, bahkan mencapai 70\%.

"Bahwa sepeda motor efisien sebagai alat transportasi, akan tetapi juga memiliki resiko kecelakaan tinggi, bahkan 73\% kecelakaan melibatkan sepeda motor". Kemudian yang menjadi korban kecelakaan lalu lintas mayoritas kalangan usia produktif dan potensial. Data 2017 menunjukkan, sebanyak 13.441 korban kecelakaan sepeda motor berusia di umur 20 hingga 29 tahun. ${ }^{4}$

Pemerintah semestinya memiliki andil untuk mengatur pembebanan kepada setiap pemilik kendaraan bermotor agar mengasuransikan tanggung jawab hukum atas kelalaian atau kesalahan pengemudi terhadap kecelakaan yang menyebabkan korban kecelakaan lalu lintas jalan. ${ }^{5}$ Undang-Undang Nomor 22 Tahun 2009 tentang Lalu Lintas dan Angkutan Jalan (UU LLAJ) telah mengamanatkan pengembangan program asuransi kecelakaan jalan dan pembentukan perusahaan asuransi kecelakaan jalan. Pasal 239 ayat (1) UU LLAJ menyatakan bahwa pemerintah mengembangkan program asuransi kecelakaan lalu lintas dan angkutan jalan.

UU LLAJ pada dasarnya sudah mengatur tanggung jawab hukum dari pengemudi yang melakukan kelalaian atau kesalahan, sehingga menyebabkan hilangnya nyawa, luka-luka, atau kerugian ekonomi yang diderita korban kecelakaan lalu lintas jalan. Wujud tanggung jawab hukum dari penyebab adalah memberikan kompensasi kepada korban kecelakaan lalu lintas jalan' Namun, UU LLAJ ternyata masih belum dapat mengakomodasi perkembangan, permasalahan, dan kebutuhan hukum di masyarakat. Hal ini dapat dilihat bahwa UU LLAJ belum mengatur sepeda motor baik roda 2 dan roda 3 sebagai salah satu moda transportasi umum. Padahal faktanya sistem transportasi umum roda 2 dan 3 telah digunakan oleh masyarakat umum sebagai salah satu moda transportasi umum. ${ }^{7}$

${ }^{4}$ Tribun Jakarta, "Menhub Sebut Angka Kecelakaan Sepeda Motor di Indonesia Capai 73 Persen", https://jakarta.tribunnews.com/2019/01/06/menhub-sebut-angka-kecelakaan-sepeda-motor-di-indonesiacapai-73-persen, diakses pada 10 Januari 2019.

5 Sulistiowati, "Pengaturan Asuransi Kecelakaan Jalan dalam Undang-Undang Nomor 22 Tahun 2009", Jurnal Mimbar Hukum, Vol. 23, No. 3, Tahun 2013, hlm. 443.

${ }^{6}$ Krisnadi Nasution, "Perlindungan Hukum terhadap Penumpang Bus Umum", Jurnal Ilmu Hukum DIH, Vol. 8, No. 16, Agustus 2012, hlm. 117.

7 Revisi UU LLAJ Lebih Praktis Ketimbang Membuat UU Baru”, http://www.hukumonline.com/ berita/baca/lt58f2d763e1edb/revisi-uu-llaj-lebih-praktis-ketimbang-membuat-uu-baru, diakses 30 Desember 2019. 
Legalisasi sepeda motor sebagai salah satu moda transportasi umum tidak hanya bertujuan untuk menjamin keselamatan penumpang, namun juga pengemudi.

Keselamatan kendaaran roda dua sangat penting, karena sepeda motor mendominasi lalu lintas dan angkutan jalan di Indonesia. Pada tahun 2016 jumlah sepeda motor yang ada di Indonesia sebanyak 104,8 juta atau enam kali lebih banyak daripada jumlah mobil yang hanya sebanyak 14,4 juta. ${ }^{8}$ Akibatnya, mayoritas kecelakaan lalu lintas di Indonesia melibatkan sepeda motor. Pada 2017, dari lebih 40.000 kasus kecelakaan lalu lintas, terdapat sekitar 32.000 kasus kecelakaan yang melibatkan sepeda motor. ${ }^{9}$ Oleh karena itu, sebagai upaya antisipatif terhadap dampaknya, perlu pengaturan lebih lanjut mengenai sepeda motor, khususnya berkaitan dengan penjaminan keselamatan dan asuransi penumpang ojek online.

Asuransi kecelakaan jalan memiliki peran penting dalam menurunkan klaim asuransi yang diakibatkan oleh kecelakaan kendaraan yang meninggal dunia maupun yang terluka. Sebelum adanya UU LLAJ, pemerintah telah menyelenggarakan dana pertanggungan wajib bagi kecelakaan penumpang dan angkutan jalan, sebagaimana diatur dalam Undang-Undang Nomor 34 Tahun 1964 tentang Dana Pertanggungan Wajib Kecelakaan Lalu-Lintas Jalan. Pertanggungan wajib tersebut dilakukan dengan mengganti kerugian penumpang angkutan umum yang menjadi korban kecelakaan diluar kesalahannya, yang dalam hal ini adalah penumpang angkutan jalan.

Pasal 137 ayat (2) UU LLAJ jo. Pasal 3 ayat (2) Peraturan Pemerintah No. 74 Tahun 2014 tentang Angkutan Jalan menyatakan bahwa pengangkutan orang dan barang dapat dilakukan dengan menggunakan kendaraan bermotor seperti sepeda motor, mobil penumpang, mobil barang dan mobil bus. Akan tetapi dalam bab yang sama bagian ketiga, angkutan orang dengan kendaraan bermotor umum menggunakan mobil penumpang umum dan mobil bus umum. Meski keberadaan ojek online sepeda motor dibutuhkan masyarakat, sebagai salah satu pelayanan angkutan orang, tetapi sepeda motor tidak diatur untuk beroperasi sebagai angkutan orang dengan kendaraan bermotor umum. ${ }^{10}$

\footnotetext{
${ }^{8}$ Badan Pusat Statistik, Statistik Indonesia 2017, Indonesia: Badan Pusat Statistik, hlm. 398-399.

${ }^{9}$ Korlantas Polri, "Statistik Laka", http://korlantas.polri.go.id/statistik-2/, diakses pada 1 Januari 2020.

${ }^{10}$ Neneng Fauziah, "Ojek dari Masa ke Masa Kajian secara Manajemen Sumber Daya Manusia”, Jurnal AKP, Vol. 7, No. 1, Februari 2017, hlm. 39.
} 
Pada dasarnya angkutan umum dibedakan menjadi 2 yaitu angkutan umum paratransit dan angkutan umum masstransit. ${ }^{11}$ Angkutan umum paratransit merupakan angkutan yang tidak memiliki rute dan jadwal tetap dalam beroperasi disepanjang rutenya, sedangkan angkutan umum masstransit merupakan angkutan yang memiliki rute dan jadwal yang tetap serta tempat pemberhentian yang jelas. Sedangkan sepeda motor sebenarnya termasuk dalam klasifikasi jenis kendaraan pribadi, namun sepeda motor banyak dijumpai di Indonesia digunakan sebagai kendaraan umum untuk mengangkut orang dan barang serta memungut biaya yang telah disepakati. ${ }^{12}$

Tidak adanya pengaturan khusus mengenai ojek sepeda motor dalam UU LLAJ maupun Peraturan Pemerintah (PP) Nomor 74 Tahun 2014 tentang Angkutan Jalan mengakibatkan ketidakpastian hukum. Ketidakpastian hukum yang dimaksud terkait kedudukan ojek sepeda motor sebagai angkutan orang dengan kendaraan bermotor umum. UU LLAJ mengatur kendaraan bermotor umum dalam Pasal 1 angka 10, bahwa "kendaraan bermotor umum adalah setiap kendaraan yang digunakan untuk angkutan barang dan/atau orang dengan dipungut bayaran". Unsur-unsur kendaraan bermotor umum dapat ditarik dari pengertian tersebut, yaitu: (1) setiap kendaraan; (2) digunakan untuk angkutan barang dan/atau orang; (3) dipungut bayaran.

Unsur-unsur tersebut apabila dibandingkan dengan pengertian ojek sepeda motor dapat dikategorikan sebagai kendaraan bermotor umum. Namun ojek sepeda motor tidak diatur dalam bagian angkutan orang dengan kendaraan bermotor umum. Masalah pengaturan ojek motor yaitu tidak diaturnya legalitas sepeda motor sebagai kendaraan bermotor umum. Berdasarkan UU LLAJ dan PP No. 74 Tahun 2014 tentang Angkutan Jalan, sepeda motor tidak termasuk dalam kriteria kendaraan yang dapat digunakan untuk kendaraan bermotor umum.

Padahal pengemudi atau perusahaan penyedia ojek sepeda motor harus bertanggungjawab atas hak-hak konsumen. Tanggung jawab ini sangat diperlukan

11 Dhevi Nayasari Sastradinata, “Aspek Pertanggungjawaban Pengemudi Ojek Online Dalam Kasus Kecelakaan Yang Melibatkan Penumpang Dilihat Dari Hukum Perlindungan Konsumen”, Jurnal Independent, Vol. 6, No. 2, Tahun 2018, hlm. 113.

12 Mailinda Eka Yuniza, "Perbandingan Undang-Undang Nomor 14 Tahun 1992 tentang Lalu Lintas Dan Angkutan Jalan Dengan Rancangan Undang-Undang Republik Indonesia tentang Lalu Lintas Dan Angkutan Jalan”, Mimbar Hukum, Vol. 21, No. 2, Juni, 2009, hlm. 259. 
apabila terjadi pelanggaran terhadap hak-hak konsumen dalam penyelenggaraan pengangkutan. Misalnya, mengakibatkan tidak selamatnya barang atau orang yang diangkut sampai tempat tujuan. Pengguna jasa ojek sepeda motor pada dasarnya dapat disebut sebagai konsumen, karena dalam Pasal 1 angka 2 UndangUndang Nomor 8 Tahun 1999 tentang Perlindungan Konsumen (UU PK) menyatakan bahwa Konsumen adalah setiap orang pemakai barang dan/atau jasa yang tersedia dalam masyarakat, baik bagi kepentingan diri sendiri, keluarga, orang lain maupun makhluk hidup lain dan tidak untuk diperdagangkan. ${ }^{13}$

Konsumen wajib dilindungi secara hukum, termasuk juga penyelesaian yang dapat ditempuh konsumen apabila mengalami kerugian terhadap penyelenggaraan jasa angkutan umum kendaraan bermotor. Salah satu kerugian yang kemungkinan dialami penumpang atau pengguna jasa ojek sepeda motor adalah terjadinya kecelakaan yang disebabkan oleh kesalahan pengemudi. Perlindungan terhadap hak-hak konsumen ini diperlukan agar pelaku usaha tidak bertindak sewenang-wenang dan selalu merugikan konsumen. ${ }^{14}$

\section{Rumusan Masalah}

Berdasarkan latar belakang di atas, rumusan masalah yang diajukan dalam penelitian ini, pertama, bagaimana pengaturan asuransi kecelakaan bagi kendaraan bermotor roda dua sebagai moda transportasi umum berbasis online ditinjau dari UU LLAJ? Kedua, bagaimana mekanisme pemenuhan asuransi atas kerugian yang timbul dari kecelakaan kendaraan bermotor roda dua sebagai moda transportasi umum berbasis online?

\section{Tujuan Penelitian}

Penelitian ini bertujuan untuk menganalisis pengaturan asuransi kecelakaan kendaraan roda dua sebagai sebagai moda transportasi umum online yang ditinjau dari UU LLAJ, serta untuk menganalisis mekanisme pemenuhan asuransi atas

${ }^{13}$ Muchtaruddin Siregar, "Perlindungan Hukum Terhadap Data Pribadi Pengguna Jasa Transportasi Online Dari Tindakan Penyalahgunaan Pihak Penyedia Jasa Berdasarkan Undang-Undang Nomor 8 Tahun 1999 Tentang Perlindungan Konsumen”, Diponegoro Law Journal, Vol. 5, No. 3, Tahun 2016, hlm. 4.

14 Ahmad Zuhairi, "Konstruksi Perlindungan Hukum Bagi Pengadu/ Pelapor Kerugian Konsumen Dari Tuntutan Pencemaran Nama Baik Oleh Pelaku Usaha/Produsen”, Jurnal Ius Kajian Hukum dan Keadilan, Vol. 3 , No. 7, April 2015, hlm. 66. 
kerugian yang timbul dari kecelakaan kendaraan bermotor roda dua sebagai moda transportasi umum berbasis online.

\section{Metode Penelitian}

Penelitian ini adalah penelitian hukum normatif, yang meletakkan hukum sebagai bangunan asas-asas, norma, kaidah dari peraturan perundang-undangan, putusan pengadilan, perjanjian, serta doktrin (ajaran). ${ }^{15}$ Penelitian ini menggunakan bahan hukum primer, meliputi Kitab Undang-Undang Hukum Perdata, Kitab Undang-Undang Hukum Dagang, Undang-Undang Nomor 22 Tahun 2009 tentang Lalu Lintas dan Angkutan Jalan, Undang-Undang Nomor 8 Tahun 1999 tentang Perlindungan Konsumen, Undang-Undang Nomor 33 Tahun 1964 tentang Dana Pertanggungan Wajib Kecelakaan Lalu-Lintas Jalan, UndangUndang Nomor 24 Tahun 2011 tentang Badan Penyelenggara Jaminan Sosial, Peraturan Menteri Perhubungan Nomor 32 Tahun 2016 tentang Penyelenggaraan Angkutan Orang dengan Kendaraan Bermotor Umum Tidak dalam Trayek. Bahan hukum sekunder, meliputi bacaan mengenai hukum dagang di Indonesia, pengangkutan darat di Indonesia, perlindungan konsumen di Indonesia, serta bacaan-bacaan yang berkaitan dengan permasalahan dalam penelitian. Bahan hukum tersier, meliputi kamus hukum serta petunjuk lain yang berhubungan dengan permasalahan dalam penelitian. Penelitian ini menggunakan pendekatan perundang-undangan (statute approach) dan pendekatan konseptual (conceptual approach). Teknik pengumpulan bahan hukum dilakukan dengan studi pustaka. Analisis bahan hukum dilakukan dengan metode preskriptif-kualitatif.

\section{Hasil Penelitian dan Pembahasan}

\section{Pengaturan Asuransi Kecelakaan Bagi Kendaraan Bermotor Roda Dua sebagai Angkutan Umum Berbasis Online}

Menurut Kamus Besar Bahasa Indonesia (KBBI) asuransi atau pertanggungan adalah perjanjian antara dua pihak, pihak yang satu berkewajiban membayar iuran dan pihak yang lain berkewajiban memberikan jaminan sepenuhnya kepada hlm. 20

15 Peter Mahmud Marzuki, Penelitian Hukum Edisi Revisi, Kencana Perdana Media Group, Jakarta, 2014, 
pembayar iuran apabila terjadi sesuatu yang menimpa pihak pertama atau barang miliknya sesuai dengan perjanjian yang dibuat. ${ }^{16}$ Peraturan mengenai asuransi di Indonesia terdapat dalam Kitab Undang-Undang Hukum Dagang (KUHD) dan diatur secara khusus di dalam Undang-Undang Nomor 40 Tahun 2014 tentang Perasuransian (UU Perasuransian).

Pasal 246 KUHD menentukan pengertian asuransi, bahwa asuransi atau pertanggungan adalah suatu perjanjian, dengan mana penanggung mengikat diri pada tertanggung dengan menerima suatu premi, untuk memberi penggantian kepadanya karena suatu kerugian, kerusakan atau kehilangan keuntungan yang diharapkan, yang mungkin akan dideritanya karena suatu peristiwa yang tidak tertentu. Pasal 247 menyebutkan bahwa hal-hal yang termasuk dalam pertanggungan antara lain dapat mengenai bahaya kebakaran, bahaya yang mengancam hasil petani yang belum dipanen, jiwa satu orang atau lebih, bahaya laut dan perbudakan, serta bahaya pengangkutan darat, sungai, dan perairan pedalaman.

Ruang lingkup pengaturan asuransi dalam KUHD terlihat sangat sempit sekali. Ruang lingkup perlindungannya hanya terhadap risiko kerugian, kerusakan, atau kehilangan keuntungan yang diharapkan akan dideritanya karena suatu peristiwa yang tidak tentu. ${ }^{17}$ Sementara, seiring dengan berkembangnya zaman, dimungkinkan munculnya risiko-risiko lain selain yang diatur dalam KUHD. Oleh karena itu, asuransi atau pertanggungan diatur lebih khusus dalam UU UU Perasuransian. Asuransi didefinisikan dalam Pasal 1 angka 1 UU 40/2014.

Perjanjian antara dua pihak, yaitu perusahaan asuransi dan pemegang polis, yang menjadi dasar bagi penerimaan premi oleh perusahaan asuransi sebagai imbalan untuk:

a. memberikan penggantian kepada tertanggung atau pemegang polis karena kerugian, kerusakan, biaya yang timbul, kehilangan keuntungan, atau tanggung jawab hukum kepada pihak ketiga yang mungkin diderita tertanggung atau pemegang polis karena terjadinya suatu peristiwa yang tidak pasti; atau

b. memberikan pembayaran yang didasarkan pada meninggalnya tertanggung atau pembayaran yang didasarkan pada hidupnya tertanggung dengan manfaat yang besarnya telah ditetapkan dan/atau didasarkan pada hasil pengelolaan dana.

\footnotetext{
${ }^{16}$ Badan Pengembangan dan Pembinaan Bahasa Kementerian Pendidikan dan Kebudayaan Republik Indonesia, "Asuransi”, https://kbbi.kemdikbud.go.id/entri/asuransi, diakses pada tanggal 25 September 2019.

17 Tuti Rastuti, Aspek Hukum Perjanjian Asuransi, Penerbit Medpress Digital, Yogyakarta, 2016, hlm. 4.
} 
Sementara itu objek dari asuransi adalah jiwa dan raga, kesehatan manusia, tanggung jawab hukum, benda dan jasa, serta semua kepentingan lainnya yang dapat hilang, rusak, rugi, dan/atau berkurang nilainya. Adapun ruang lingkup usaha perasuransian menurut Pasal 2 dan Pasal 3 Undang-Undang No. 40 Tahun 2014 tentang Perasuransian adalah sebagai berikut:

1. Perusahaan asuransi umum hanya dapat menyelenggarakan:

a. Usaha Asuransi Umum, termasuk lini usaha asuransi kesehatan dan lini usaha asuransi kecelakaan diri; dan

b. Usaha Reasuransi untuk risiko Perusahaan Asuransi Umum lain.

2. Perusahaan asuransi jiwa hanya dapat menyelenggarakan Usaha Asuransi Jiwa termasuk lini usaha anuitas, lini usaha asuransi kesehatan, dan lini usaha asuransi kecelakaan diri.

3. Perusahaan reasuransi hanya dapat menyelenggarakan Usaha Reasuransi.

4. Perusahaan asuransi umum syariah hanya dapat menyelenggarakan:

a. Usaha Asuransi Umum Syariah, termasuk lini usaha asuransi kesehatan berdasarkan Prinsip Syariah dan lini usaha asuransi kecelakaan diri berdasarkan Prinsip Syariah; dan

b. Usaha Reasuransi Syariah untuk risiko Perusahaan Asuransi Umum Syariah lain.

5. Perusahaan asuransi jiwa syariah hanya dapat menyelenggarakan Usaha Asuransi Jiwa Syariah termasuk lini usaha anuitas berdasarkan Prinsip Syariah, lini usaha asuransi kesehatan berdasarkan Prinsip Syariah, dan lini usaha asuransi kecelakaan diri berdasarkan Prinsip Syariah.

6. Perusahaan reasuransi syariah hanya dapat menyelenggarakan Usaha Reasuransi Syariah.

Pada dasarnya, asuransi terdiri dari asuransi kerugian, asuransi jiwa, asuransi sosial, dan asuransi varia yang diatur dalam berbagai undang-undang. ${ }^{18}$ Berangkat dari uraian di atas, dapat diketahui bahwa asuransi merupakan manajemen pengendalian risiko dari suatu peristiwa yang tidak terduga dan dapat terjadi sewaktu-waktu yang dapat dilakukan dengan pengalihan risiko maupun pembagian risiko. Asuransi bertujuan untuk memberikan perlindungan nilai ekonomi kepada seseorang terhadap berbagai risiko kehidupan. ${ }^{19}$ Risiko adalah 
ketidakpastian akan terjadinya suatu peristiwa yang dapat menimbulkan kerugian ekonomis. ${ }^{20}$ Adapun bentuk-bentuk risiko antara lain:21

1. Risiko murni, adalah risiko yang akibatnya hanya ada 2 macam, yakni rugi atau break even. Contoh: pencurian, kecelakaan atau kebakaran.

2. Risiko spekulatif, adalah risiko yang akibatnya ada 3 macam, yakni rugi, untung atau break even. Contoh: judi

3. Risiko partikular, adalah risiko yang berasal dari individu dan dampaknya lokal.Contoh: pesawat jatuh, tabrakan mobil dan kapal kandas.

4. Risiko fundamental, adalah risiko yang bukan berasal dari individu dan dampaknya luas. Contoh: angin topan, gempa bumi dan banjir.

Pada manajemen perlindungan resiko murni berupa kecelakaan, jenis asuransi yang tepat untuk digunakan adalah asuransi kecelakaan diri. Asuransi jenis ini untuk menjamin risiko cacat tetap total atau meninggal dunia karena kecelakaan. ${ }^{22}$ Namun, asuransi ini hanya cenderung dimiliki oleh masyarakat berpenghasilan, sehingga masyarakat yang berkategori tidak mampu relatif kesulitan umengakses atau mendaftarkan risiko pada asuransi. Pemerintah menciptakan 2 produk asuransi sosial dalam rangka memberikan perlindungan dasar kepada masyarakat. Asuransi tersebut adalah Asuransi Kecelakaan Penumpang Alat Angkutan Umum yang dilaksanakan berdasarkan UndangUndang Nomor 33 Tahun 1964 entang Dana Pertanggungan Wajib Kecelakaan Lalu-Lintas (UU 33/1964), serta Asuransi Tanggung Jawab Menurut Hukum Terhadap Pihak Ketiga yang dilaksanakan berdasarkan Undang-Undang Nomor 34 Tahun 1964 Tentang Dana Kecelakaan Lalu Lintas Jalan. ${ }^{23}$

Pemerintah mendirikan PT. Jasa Raharja (Persero) untuk melaksanakan amanat dari UU 33/1964 dan UU 34/1964. PT. Jasa Raharja (Persero) adalah Badan Usaha Milik Negara (BUMN) yang bergerak di bidang asuransi berdasarkan undang-undang dan Peraturan Pemerintah. PT. Jasa Raharja (Persero) menerima iuran dan sumbangan wajib dari pemilik/ pengusaha angkutan lalu lintas jalan dan

${ }^{20}$ Pan Pacific,"Pengertian Asuransi dan Risiko",http://panfic.com/id/insurance-knowledge/pengertianasuransi-dan-risiko/, diakses pada tanggal 25 September 2019.

${ }^{21}$ Resista Vikaliana, "Faktor-faktor Risiko dalam Perusahaan Jasa Pengiriman”, Jurnal Logistik Indonesia, Vol. 1, No. 1, April 2017, hlm. 70.

22 Axa Mandiri, “Asuransi Kecelakaan Diri”, https://www.axa-mandiri.co.id/produk/asuransi-kecelakaandiri-2/, diakses pada tanggal 25 September 2019.

${ }^{23}$ Jasa Raharja, “Lingkup Jaminan”, https://www.jasaraharja.co.id/layanan/lingkup-jaminan, diakses pada tanggal 25 September 2019. 
penumpang angkutan umum serta menyalurkannya kembali melalui santunan asuransi kecelakaan lalu lintas jalan. ${ }^{24}$ Konsep pemberian dana pertanggungan kepada penumpang yang mengalami kerugian oleh kendaraan bermotor umum menurut UU 33/1964 dengan cara wajib membayar iuran melalui pengusaha/pemilik yang bersangkutan. Pembayaran ini untuk menutup akibat kerugian yang disebabkan kecelakaan penumpang dalam perjalanan. Iuran tersebut digunakan untuk mengganti kerugian yang berhubungan dengan kematian dan cacat tetap yang dialami penumpang akibat dari kendaraan bermotor umum.

Pasal 1 angka 10 UU LLAJ menentukan bahwa kendaraan bermotor umum adalah setiap kendaraan yang digunakan untuk angkutan barang dan/atau orang dengan dipungut bayaran. Jenis kendaraan bermotor terdiri atas sepeda motor, mobil penumpang, mobil bus, mobil barang, dan kendaraan khusus. Dari kelima jenis kendaraan bermotor tersebut, hanya 4 yang dikategorikan sebagai kendaraan bermotor umum, kecuali sepeda motor. Kendaraan bermotor umum yang digunakan sebagai sarana angkutan umum harus memenuhi standar pelayanan minimal yang meliputi keamanan, keselamatan, kenyamanan, keterjangkauan dan keteraturan, sehingga kendaraan tersebut dapat dikatakan laik jalan. Hal ini dimaksudkan agar sesuai dengan tujuan penyelenggaraan lalu lintas dan angkutan jalan sebagaimana Pasal 3 UU LLAJ. ${ }^{25}$

Ada 2 faktor keselamatan dalam aktivitas pengangkutan yaitu active safety dan pasive safety. Active safety dipastikan semua kendaraan memilikinya yaitu rem. Active Safety digunakan untuk menghindari kecelakaan, sedangkan pasive safety tidak semua kendaraan memilikinya, contohnya yang terdapat pada mobil, yaitu airbag dan sabuk pengaman sehingga jika ada kecelakaan pada pengendara dan penumpang tidak akan berakibat fatal. Oleh karena itu sepeda motor ditinjau dari

${ }^{24}$ Fahrul Rozy Nasution, "Peran dan Tanggung Jawab PT. Jasa Raharja (Persero) Dalam Memberikan Santunan Asuransi Terhadap Korban Kecelakaan Lalu Lintas Jalan (Studi Pada PT. Jasa Raharja (Persero) Cabang Rantauprapat), Jurnal Civil Law, Vol. 2, No. 2, Tahun 2013, hlm. 2.

25 'Lalu Lintas dan Angkutan Jalan diselenggarakan dengan tujuan: (a) terwujudnya pelayanan Lalu Lintas dan Angkutan Jalan yang aman selamat, tertib, lancar, dan terpadu dengan moda angkutan lain untuk mendorong perekonomian nasional, memajukan kesejabteraan umum, memperkukuh persatuan dan kesatuan bangsa, serta mampu menjunjung tinggi martabat bangsa; (b) terwujudnya etika berlalu lintas dan budaya bangsa; dan (c) terwujudnya penegakan bukum dan kepastian bukum bagi masyarakat." 
sisi safety tidak layak dijadikan angkutan umum, karena jika terjadi kecelakaan akan berakibat fatal. Kendaraan roda dua atau sepeda motor hanya diizinkan untuk mengangkut barang. Pasal 10 ayat (4) huruf a PP No. 74 Tahun 2014 tentang Angkutan Jalan (PP Angkutan Jalan) menentukan "lebar barang muatan tidak boleh melebihi setang kemudi". Sepeda motor dapat mengangkut orang, namun bukan sebagai angkutan umum. ${ }^{26}$

Seiring dengan perkembangan zaman dan teknologi, berbagai sektor maupun bidang dituntut untuk mengikuti perkembangan zaman masa kini, salah satunya adalah sektor pengangkutan. Pengangkutan adalah perpindahan tempat, baik mengenai benda-benda maupun orang, karena perpindahan itu mutlak diperlukan untuk mencapai dan meninggikan manfaat secara efisien. ${ }^{27}$ Kini muncul terobosan baru di bidang angkutan umum sebagai transportasi umum yang berbasis online dalam rangka meningkatkan efisiensi di bidang pengangkutan darat, khususnya angkutan umum.

Terobosan ini menggunakan kendaraan bermotor roda dua sebagai angkutan umum yang dapat diakses melalui smartphone. Hal ini merupakan suatu jawaban atas kebutuhan masyarakat akan transportasi publik yang memadai, efisien dan praktis. Semakin tingginya tuntutan mobilitas masyarakat, tentunya membutuhkan sarana transportasi yang dapat memberikan pergerakan dan perpindahan dari satu tempat ke tempat yang lain dengan cepat, walaupun jarak tempuhnya jauh. ${ }^{28}$ Jenis kendaraan bermotor yang digunakan sebagai sarana angkutan umum berbasis online ini adalah mobil dan sepeda motor. Permasalahan kemudian timbul pada jenis kendaraan yang digunakan sebagai sarana angkutan umum berupa sepeda motor.

Sepeda motor bukan merupakan kendaraan yang dapat digunakan sebagai angkutan umum sebagaimana telah diulas sebelumnya. Pengaturan mengenai sepeda motor sebagai sarana transportasi di Indonesia terdapat dalam UU LLAJ. Pasal 1 UU LLAJ mendefinisikan kendaraan bermotor umum sebagai berikut:

${ }^{26}$ Hamsona, Dewi Ayu, "Perlindungan Hukum Terhadap Keselamatan Penumpang Kendaraan Sepeda Motor Yang Digunakan Untuk Kepentingan Masyarakat”, Jurnal Novum, Vol. 1 No. 2, 2019, hlm. 2-3

27 Sinta Uli, Pengangkutan, Suatu Tinjanan Hukum Multimoda Transport, Angkutan Laut, Angkutan Darat, Angkutan Udara, Medan, USU Press, 2006, hlm. 20

28 Slaudiya Anjani Septi Damayanti, "Transportasi Berbasis Aplikasi Online: Go-Jek Sebagai Sarana Transportasi Masyarakat Kota Surabaya”, Jurnal Komunitas, Vol. 6, No. 3, Tahun 2017, hlm. 3. 
"Kendaraan bermotor umum adalah setiap kendaraan yang digunakan untuk angkutan barang dan/atau orang dengan dipungut bayaran".

Pasal 47 UU LLAJ mengelompokkan kendaraan menjadi 2, yaitu kendaraan bermotor dan kendaraan tidak bermotor. Terkait kendaraan bermotor, jenisnya adalah sepeda motor; mobil penumpang; mobil bus; mobil barang; dan kendaraan khusus. Kendaraan bermotor tersebut mempunyai fungsi sebagai kendaraan motor umum perseorangan dan kendaraan bermotor umum. Kelima jenis transportasi tersebut menunjukkan bahwa hanya mobil penumpang, mobil bus, dan mobil barang yang mempunyai fungsi sebagai kendaraan bermotor umum. ${ }^{29}$ Kendaraan yang dapat digunakan untuk angkutan umum dan/atau barang hanya dapat dilakukan dengan kendaraan bermotor umum.

Berdasarkan penjelasan di atas, maka sepeda motor tidak termasuk sebagai angkutan umum karena bukan termasuk kendaraan bermotor umum. ${ }^{30}$ Selain UU LLAJ, pengaturan mengenai sepeda motor terdapat dalam Peraturan Pemerintah Nomor 74 Tahun 2014 tentang Angkutan Jalan (PP 74/2014), yang merupakan peraturan turunan dari UU LLAJ. Pasal 1 angka 1 PP 74/2014 mendefinisikan angkutan adalah perpindahan orang dan/atau barang dari satu tempat ke tempat lain dengan menggunakan kendaraan di ruang lalu lintas jalan. Pasal 3 PP 74/2014 menentukan bahwa angkutan orang dan/atau barang dapat menggunakan kendaraan bermotor dan kendaraan tidak bermotor. Untuk kendaraan bermotor dapat dikategorikan antara lain: sepeda motor; mobil penumpang; mobil bus; dan mobil barang. ${ }^{31}$ PP 74/2014 mengakui keberadaan sepeda motor sebagai sarana transportasi yang dapat digunakan sebagai angkutan orang dan/atau barang.

Ketidakjelasan pengaturan mengenai fungsi sepeda motor sebagai kendaraan bermotor umum sebagaimana diatur dalam UU LLAJ, tidak serta-merta menjadikan penggunaan sepeda motor sebagai angkutan umum terhenti. Hingga saat ini, perusahaan penyedia jasa angkutan umum berbasis online, seperti Grab dan Gojek, masih berjalan seperti biasa. Hal ini berpotensi menimbulkan permasalahan,

\footnotetext{
29 Pasal 1 Undang-Undang No. 22 Tahun 2009 tentang Lalu Lintas dan Angkutan Jalan

${ }^{30}$ Gusti Ayu Putu Yindri Laksmiwiyani, "Legalitas Kendaraan Roda Dua sebagai Angkutan Umum”, Jurnal Kertha Semaya, Vol. 6, No.6, Mei 2018, hlm. 10.

31 Pasal 3 ayat (2) Peraturan Pemerintah Republik Indonesia Nomor 74 Tahun 2014 tentang Angkutan Jalan
} 
khususnya bagi angkutan umum dengan sepeda motor, apabila terjadi kecelakaan. Kecelakaan ini dapat merugikan 2 (pihak) yakni pengemudi dan penumpang. Produk asuransi sosial wajib bagi masyarakat oleh PT. Jasa Raharja tidak dapat melindungi masyarakat yang menggunakan kendaraan sepeda motor sebagai sarana angkutan umum, karena sepeda motor tidak termasuk kendaraan bermotor umum. ${ }^{32}$

Pada saat ini UU LLAJ masih kurang efektif dalam implementasinya, karena banyak ketentuan di dalam UU LLAJ yang belum ditindaklanjuti dengan petunjuk teknis, bahkan membutuhkan petunjuk teknis yang sangat banyak. Ada beberapa permasalahan terkait penyelenggaraan lalu lintas dan angkutan jalan, diantaranya adalah, Pertama, kurangnya koordinasi antar lembaga dalam penegakan peraturan. Peraturan lalu lintas dibuat oleh Dinas Perhubungan namun dalam penindakan dilakukan oleh Kepolisian yang tidak dibawah komando Pemerintah Daerah. Kedua, angkutan umum berbasis online (daring) yang semakin marak muncul saat ini, apabila tidak bisa dikendalikan oleh pemerintah, justru akan mengancam rusaknya sistem angkutan umum yang sudah ada, dan dapat mengganggu jaringan jalan dan lalu lintas orang, barang, dan kendaraan lain.

Hal-hal yang perlu disesuaikan kembali antara lain persyaratan teknis dan layak jalan (Pasal 48), modifikasi dan uji tipe (Pasal 51), perlengkapan kendaraan bermotor (Pasal 57), persyaratan dan tata cara penyelenggaraan bengkel umum (Pasal 60), persyaratan keselamatan (Pasal 61), serta kriteria dan tata cara pengenaan sanksi administratif kepada pihak mitra khususnya pada transportasi ojek online (Pasal 76). Maka dari itu, berdasarkan UU 34/1964, pemerintah mewajibkan pengusaha atau pemilik alat angkutan lalu lintas jalan untuk memberi sumbangan wajib setiap tahun dengan besaran yang ditentukan oleh peraturan pemerintah. Sumbangan wajib ini akan digunakan untuk menutup akibat kerugian karena kecelakaan lalu lintas jalan korban/ahli waris yang bersangkutan. Ketentuan ini berlaku bagi setiap kendaraan bermotor umum yang digunakan sebagai angkutan umum orang/barang.

\footnotetext{
${ }^{32}$ Ratna Dewi, “Perlindungan Hukum Terhadap Korban/Ahli Waris Akibat Kecelakaan Lalu Lintas Jalan”, Syiah Kuala Law Journal, Vol.1, No.2, Agustus 2017, hlm. 126.
} 
Terdapat tumpang tindih aturan antara UU No. 33/1964 dan UU No. 34/1964 dengan Pasal 239 UU tentang LLAJ tentang penyelenggaraan asuransi terkait kecelakaan kendaraan. Hal ini menimbulkan ketidakpastian karena dalam ketentuan tersebut obyek pertanggungannya sama. Selain itu, perlu juga dilakukan penyesuaian pada penindakan sanksi administratif (Pasal 244).

Perusahaan penyedia jasa transportasi umum berbasis online dengan jenis kendaraan sepeda motor sebagai sarana angkutannya, dapat mendaftarkan perusahaan dan pekerjanya ke perusahaan asuransi swasta. Seperti dilansir di website resmi PT. Aplikasi Karya Anak Bangsa (GO-JEK). ${ }^{33}$ Go-Jek telah bekerja sama dengan perusahaan asuransi swasta Allianz dalam rangka memberikan manfaat perlindungan berupa jaminan keselamatan bagi pengguna atau penumpang Go-Ride. Hal ini merupakan suatu upaya untuk memberikan perlindungan terhadap keselamatan penumpang pengguna transportasi umum jenis kendaraan sepeda motor.

Upaya lain yang dapat dilakukan perusahaan penyedia jasa transportasi umum berbasis online adalah membuat produk asuransi sendiri. Perusahaan Grab misalnya, menciptakan produk Asuransi Kecelakaan Personal Grab dalam rangka memberikan perlindungan jaminan keselamatan kepada pengemudi dan penumpang Grab Bike. Upaya-upaya seperti ini dilakukan karena ketidakjelasan pengaturan mengenai fungsi sepeda motor menurut UU LLAJ. UU LLAJ mengatur bahwa sepeda motor tidak termasuk kendaraan bermotor untuk angkutan umum, sedangkan seiring berkembangnya zaman dan teknologi, kini sepeda motor marak digunakan sebagai sarana angkutan umum.

Sampai saat ini sepeda motor statusnya seperti "anak haram" yang dirindukan kehadirannya sebagai angkutan umum oleh masyarakat. Penggunaan sepeda motor sebagai angkutan umum seharusnya dapat disikapi sebijak mungkin dengan segera memberikan payung hukum yang jelas serta menjadikannya salah satu modal transportasi untuk angkutan umum. Hal tersebut dikarenakan fakta sebagaimana juga telah disampaikan dalam pendahuluan membuktikan bahwa

\footnotetext{
33 Go-Ride, "Ketahui Informasi lengkap Asuransi Kecelakaan Go-Ride", https://www.gojek.com/blog/asuransi/, diakses pada tanggal 25 September 2019.
} 
penggunaan motor sebagai angkutan umum telah jumlahnya yang semakin banyak.

Penggunaan sepeda motor perlu diatur syarat-syaratnya dengan ketat untuk dapat lulus dan dapat digunakan sebagai angkutan umum. Sepeda motor juga hanya boleh beroperasi sebagai angkutan umum dengan jarak tertentu. ${ }^{34}$ Selain itu, dalam rangka mengendalikan sepeda motor sebagai angkutan umum, maka diperlukan pembatasan kuota operasi. Terkait pembatasan kuota tersebut, kewenangannya diberikan kepada pemerintah daerah. Pengaturan tersebut diperlukan supaya angkutan umum tetap dapat diselenggarakan dalam upaya memenuhi kebutuhan angkutan yang selamat, aman, nyaman, dan terjangkau.

\section{Mekanisme Pemenuhan Asuransi Akibat Kecelakaan Kendaraan Bermotor Roda Dua sebagai Moda Transportasi Umum Berbasis Online}

Tingginya jumlah korban kecelakaan lalu lintas membuat negara merasa perlu untuk memberikan jaminan bagi korban kecelakaan. Pasal 34 ayat (2) UUD NRI 1945 menyatakan, "Negara mengembangkan sistem jaminan sosial bagi seluruh rakyat dan memberdayakan masyarakat yang lemah dan tidak mampu sesuai martabat kemanusiaan." Pasal tersebut menghendaki agar negara mengembangkan dan menyelenggarakan sistem jaminan sosial. Secara umum ada tiga faktor utama penyebab kecelakaan lalu lintas, yaitu faktor pengguna jalan (road user), faktor kendaraan (vehicle), dan faktor lingkungan jalan (road environment). Kecelakaan yang terjadi pada umumnya tidak hanya disebabkan oleh satu faktor saja, melainkan hasil interaksi antar faktor lain. ${ }^{35}$

Asuransi adalah salah satu bentuk pengendalian risiko, dengan cara mengalihkan/mentransfer risiko tersebut dari pihak pertama ke pihak lain, dalam hal ini adalah kepada perusahaan asuransi. Pelimpahan tersebut berdasarkan dengan aturan-aturan hukum dan prinsip-prinsip yang berlaku secara universal, yang dianut baik oleh pihak pertama maupun pihak lain. Sebagaimana diatur

\footnotetext{
${ }^{34}$ M. Nurfaik, "Kontroversi Penggunaan Sepeda Motor Sebagai Angkutan Umum”, https://rechtsvinding.bphn.go.id/jurnal_online/Naskah\%20Pak\%20Nurfaik\%20Fix.pdf, diakses pada tanggal 25 September 2019.

${ }^{35}$ Hapsari, Mertha, "Rekonstruksi Program Perlindungan Dasar Melalui Program Pertanggungan Wajib Kecelakaan Penumpang dan Lalu Lintas". Jurnal Pembangunan Hukum Indonesia, Vol. 1 No. 1 2019, hlm. 65
} 
dalam Pasal 1 UU Perasuransian, Setiap nasabah yang merasa dirugikan berhak untuk menuntut pertanggungjawaban hukum dari pihak yang telah merugikannya.

Pemerintah telah membentuk asuransi PT. Jasa Raharja (Persero) selanjutnya disebut dengan PT. Jasa Raharja untuk meringankan dampak yang dialami korban kecelakaan lalu lintas dan ahli warisnya. PT. Jasa Raharja merupakan BUMN yang diatur lebih lanjut dalam Undang-Undang Nomor 19 Tahun 1960 tentang Perusahaan Negara sebagaimana telah diperbaharui dengan Undang-Undang Nomor 19 Tahun 2003 tentang Badan Usaha Milik Negara (UU BUMN). PT. Jasa Raharja khusus mengelola asuransi kecelakaan lalu lintas di jalan raya. ${ }^{36}$

Perlindungan hukum dilakukan dengan memberikan pengayoman terhadap Hak Asasi Manusia yang dirugikan oleh orang lain dan perlindungan itu diberikan kepada masyarakat agar dapat menikmati semua hak-hak yang diberikan oleh hukum. ${ }^{37}$ Asuransi kecelakaan merupakan bagian penting dari penyelenggaraan usaha angkutan umum untuk menjamin perlindungan bagi para pengguna (warga negara). Pasal 237 UU LLAJ secara tegas mewajibkan perusahaan angkutan umum untuk mengikuti program asuransi kecelakaan sebagai wujud tanggung jawabnya memberikan jaminan bagi para penumpang. 38

Berdasarkan Peraturan Pemerintah Nomor 39 Tahun 1980 tentang Pengalihan Bentuk Perusahaan Umum Asuransi Kerugian 'Jasa Raharja' menjadi Perusahaan Perseroan (Persero). Perusahaan asuransi kecelakaan lalu lintas dan pengangkutan jalan yang dimaksud oleh Pasal 239 UU LLAJ adalah PT. Jasa Raharja (Persero). Kepatuhan untuk melaksanakan ketentuan Pasal 239 UU LLAJ sebagai wujud tanggung jawab perusahaan pengangkutan atas jaminan bagi korban kecelakaan berkaitan erat dengan pemberian izin usaha angkutan. ${ }^{39}$

Permasalahan kemudian timbul ketika sepeda motor tidak tergolong kendaraan bermotor untuk angkutan umum menurut UU LLAJ. Atas permasalahan tersebut perusahaan ojek online (GO-JEK) secara mandiri

\footnotetext{
${ }^{36}$ Dewi, Ratna, "Perlindungan Hukum..., Op. Cit., hlm. 125

${ }^{37}$ Satjipto Rahardjo, Permasalahan Hukum di Indonesia, Alumni, Bandung, 1983, hlm. 121.

38 Pasal 239 UU LLAJ menentukan bahwa pemerintah mengembangkan program asuransi kecelakaan lalu lintas dengan pengangkutan jalan, dan untuk tujuan tersebut, pemerintah membentuk perusabaan asuransi kecelakaan lalu lintas dan pengangkutan jalan sesuai dengan peraturan perundang-undangan.

${ }^{39}$ Hilda Yunita, "Karakteristik Hubungan Hukum Dalam Asuransi Jasa Raharja Terhadap Klaim Korban Kecelakaan Angkutan Umum”, Yuridika, Vol. 30 No. 3, tahun 2015, hlm. 8.
} 
memberikan perlindungan berupa asuransi untuk penumpang apabila terjadi kecelakaan. Penumpang dapat mengklaim asuransi pada perusahaan yang telah bekerja sama dengan perusahaan ojek online (GO-JEK). ${ }^{40}$ Keselamatan penumpang merupakan hal yang sangat patut diperhatikan bagi penyedia jasa kendaraan. Namun, karena kendaraan roda dua merupakan transportasi perseorangan menimbulkan sepeda motor atau kendaraan roda dua tidak layak disebut sebagai angkutan umum, sehingga tidak dapat diakomodasi dalam sistem asuransi Jasa Raharja.

Perlu instrumen hukum yang memperjelas kedudukan dan fungsi sepeda motor, agar pemerintah dapat melakukan pengaturan sekaligus pengendalian terhadap jumlah dan wilayah operasionalnya, melalui revisi UU LLAJ. Adapun materi di dalam UU LLAJ yang kiranya perlu mendapat revisi adalah ketentuanketentuan terkait dengan Pasal 1 angka 1 tentang definisi perusahaan angkutan umum, Bab X tentang Angkutan Umum, dan Pasal 215 tentang kewajiban perusahaan angkutan umum.

Apabila penumpang mengalami kecelakaan, maka penumpang berhak mendapatkan ganti rugi berupa santunan dari GO-JEK. Syarat dan ketentuan PT. GO-JEK menyebutkan bahwa GO-JEK Indonesia memberikan santunan musibah kecelakaan kepada seluruh pelanggan GO-JEK yang menggunakan layanan GO-RIDE. Konsumen akan menerima penggantian sampai dengan Rp. 10.000.000,- dan untuk biaya rumah sakitnya mencapai Rp. 5.000.000,-. Penumpang berhak meminta pertanggungjawaban pihak GO-JEK apabila pihak GO-JEK tidak memberikan perlindungan hukum terhadap penumpang berupa santunan seperti ketentuan tersebut. 41

Apabila dari pihak GO-JEK tidak dapat memenuhi syarat dan ketentuan tersebut, maka pihak GO-JEK dapat dikategorikan wanprestasi. Selain itu, Pasal 7 huruf f Undang-Undang Nomor 8 Tahun 1999 tentang Perlindungan Konsumen (UU PK) yang berbunyi bahwa pelaku usaha wajib memberi kompensasi, ganti rugi dan/atau penggantian atas kerugian akibat penggunaan, pemakaian dan pemanfaatan

${ }^{40}$ Rahmadyarti, Azka, "Pelaksanaan Asuransi Jiwa Terhadap Penumpang Ojek Online (Studi PT. GO-JEK Indonesia dan PT. Asuransi ALLIANZ Indonesia”, Diponegoro Law Journal, Vol 6, No. 2 2017, hlm. 9.

${ }^{41}$ Suwari Akhmaddhian, "Perlindungan Hukum terhadap Konsumen dalam Transaksi Jual Beli secara Elektronik di Indonesia", Jurnal Unifikasi, Vol. 3, No. 2, Juli 2016, hlm. 53. 
barang dan/atau jasa yang diperdagangkan, sedangkan Pasal 60 ayat (1) sampai ayat (3) UU PK yang berbunyi Badan Penyelesaian Sengketa Konsumen berwenang menjatuhkan sanksi administratif terhadap pelaku usaha yang melanggar Pasal 19 ayat (2) dan ayat (3), Pasal 20, Pasal 25 dan Pasal 26. Ayat (2) yang berbunyi sanksi administratif berupa penetapan ganti rugi paling banyak Rp. 200.000.000,00 (dua ratus juta rupiah)" dan ayat (3) yang berbunyi tata cara penetapan sanksi adminstratif sebagaimana yang dimaksud pada ayat (1) diatur lebih lanjut dalam peraturan perundang-undangan. ${ }^{42}$

Masalah transportasi berbasis online ini memerlukan penanganan yang serius, sehingga pemerintah harus melakukan upaya sinkronisasi dan harmonisasi terkait berbagai peraturan yang mengatur transportasi online. Transportasi online dengan segala kemudahannya memang masih menyisakan masalah hukum. Belum adanya aturan atau payung hukum yang jelas, sehingga seringkali menjadikan transportasi online sebagai sesuatu yang dianggap ilegal. Lambatnya pemerintah dalam menyediakan payung hukum menjadi penyebab munculnya permasalahan terkait transportasi berbasis aplikasi online.

Upaya yang saat ini dilakukan oleh pemerintah dalam melakukan sinkronisasi dan harmonisasi peraturan yang terkait dengan angkutan bukan umum berbasis online hanya dilakukan dengan melakukan revisi dan pencabutan peraturan perundang-undangan setelah adanya uji materiil oleh Mahkamah Agung. Hal tersebut tidak efektif karena peraturan angkutan bukan umum berbasis online kerap berganti-ganti yang menandakan peraturan tersebut belum dapat berlaku secara efektif dan belum memberikan kepastian hukum.

Peraturan yang diterbitkan pada dasarnya untuk memberikan perlindungan bagi masyarakat, pengemudi bahkan bagi perusahaan transportasi online. Hal ini merupakan bentuk peranan hukum dalam pembangunan. Mengingat penggunaan aplikasi online ini merupakan fenomena yang terjadi dalam perkembangan kehidupan masyarakat. Keberadaan perusahaan transportasi online dapat mendukung usaha pembangunan. Hukum positif menjamin kepastian hidup, tetapi baru menjadi lengkap bila disusun sesuai dengan prinsip keadilan.

42 Philipus M. Hadjon, Perlindungan Hukum Bagi Rakyat Indonesia, Bina Ilmu, Surabaya, 1987, hlm. 36. 


\section{Penutup}

Berdasarkan hasil penelitian dan pembahasan di atas, maka penulis berkesimpulan: pertama, bahwa produk asuransi sosial wajib bagi masyarakat oleh PT. Jasa Raharja tidak dapat melindungi masyarakat yang menggunakan kendaraan bermotor roda dua sebagai sarana angkutan umum, karena kendaraan bermotor roda dua tidak termasuk kendaraan bermotor umum menurut UU LLAJ. Namun, perusahaan penyedia jasa transportasi umum berbasis online dengan jenis kendaraan bermotor roda dua, dapat mendaftarkan perusahaan dan pekerjanya ke perusahaan asuransi swasta. Upaya lain yang dapat dilakukan perusahaan penyedia jasa transportasi umum berbasis online adalah dengan membuat produk asuransi sendiri.

Kedua, setiap orang berhak memeroleh keselamatan dan keamanan saat menggunakan jasa angkutan kendaraan bermotor roda dua. Apabila asuransi tidak diberikan, maka penyedia jasa angkutan umum roda dua (online) dapat dikategorikan wanprestasi berdasarkan syarat dan ketentuan yang telah dibuatnya. Berdasarkan Pasal 60 ayat (1) sampai ayat (3) Undang-Undang Nomor 8 Tahun 1999 tentang Perlindungan Konsumen, Badan Penyelesaian Sengketa Konsumen juga berwenang menjatuhkan sanksi administratif. UU LLAJ perlu direvisi sesuai dengan perkembangan masyarakat, agar pelindungan atas risiko kecelakaan dapat terpenuhi secara optimal. Khususnya berkaitan dengan pertanggungjawaban perusahaan angkutan umum maupun perusahaan penyedia aplikasi yang berbasis teknologi. Diperlukan perumusan pasal yang lebih jelas dan terperinci kapan dan kriteria perbuatan yang dapat dipertanggungjawabkan kepada perusahaan angkutan umum berbasis teknologi, serta pihak yang harus mewakili perusahaan dalam perasuransian hendaknya dipertegas.

\section{Daftar Pustaka}

\section{Buku}

Abdulnakir Muhammad, Hukum Pengangkutan Niaga, Citra Aditya Bakti, Bandung, 1998.

Marzuki, Mahmud Peter, Penelitian Hukum Edisi Revisi, Kencana Perdana Media Group, Jakarta, 2014. 
Philipus M. Hadjon, Perlindungan Hukum Bagi Rakyat Indonesia, Bina Ilmu, Surabaya, 1987.

Rahardjo, Satjipto, Permasalahan Hukum di Indonesia, Alumni, Bandung, 1983.

Rastuti, Tuti, Aspek Hukum Perjanjian Asuransi, Penerbit Medpress Digital, Yogyakarta, 2016.

Uli, Sinta, Pengangkutan, Suatu Tinjauan Hukum Multimoda Transport Angkutan Laut, Angkutan Darat, Angkutan Udara, USU Press, Medan, 2006.

Warpani, P. Suwardjoko, Merencanakan Sistem Perangkutan, Penerbit ITB, Bandung, 1990.

\section{Jurnal}

Akhmaddhian, Suwari, "Perlindungan Hukum terhadap Konsumen dalam Transaksi Jual Beli secara Elektronik di Indonesia", Jurnal Unifikasi, Vol. 3, No. 2, Juli 2016.

Damayanti, Slaudiya Anjani Septi, “Transportasi Berbasis Aplikasi Online: Go-Jek Sebagai Sarana Transportasi Masyarakat Kota Surabaya", Jurnal Komunitas, Vol. 6, No. 3, Tahun 2017.

Dewi, Ratna, "Perlindungan Hukum Terhadap Korban/Ahli Waris Akibat Kecelakaan Lalu Lintas Jalan", Syiah Kuala Law Journal, Vol.1, No.2, Agustus 2017.

Fauziah, Neneng, “Ojek dari Masa ke Masa Kajian secara Manajemen Sumber Daya Manusia", Jurnal AKP, Vol. 7, No. 1, Februari 2017.

Hamsona, Dewi Ayu, "Perlindungan Hukum Terhadap Keselamatan Penumpang Kendaraan Sepeda Motor Yang Digunakan Untuk Kepentingan Masyarakat", Jurnal Novum, Vol. 1 No. 2, 2019.

Hapsari, Mertha, “Rekonstruksi Program Perlindungan Dasar Melalui Program Pertanggungan Wajib Kecelakaan Penumpang dan Lalu Lintas". Jurnal Pembangunan Hukum Indonesia, Vol. 1 No. 12019.

Laksmiwiyani, Gusti Ayu Putu Yindri, “Legalitas Kendaraan Roda Dua sebagai Angkutan Umum", Jurnal Kertha Semaya, Vol. 6, No. 6, Mei 2018.

Nasution, Dian Mandayani Ananda, “Tinjauan Hukum Terhadap Layanan Transaksi Dan Transportasi Berbasis Aplikasi Online", RESAM, Vol. 4, No. 1, April, 2018.

Nasution, Fahrul Rozy, "Peran dan Tanggung Jawab PT. Jasa Raharja (Persero) Dalam Memberikan Santunan Asuransi Terhadap Korban Kecelakaan Lalu Lintas Jalan (Studi Pada PT. Jasa Raharja (Persero) Cabang Rantauprapat), Jurnal Civil Law, Vol. 2, No. 2, Tahun 2013.

Nasution, Krisnadi, "Perlindungan Hukum terhadap Penumpang Bus Umum”, Jurnal Ilmu Hukum DIH, Vol. 8, No. 16, Agustus 2012. 
Rahmadyarti, Azka, "Pelaksanaan Asuransi Jiwa Terhadap Penumpang Ojek Online (Studi PT. GO-JEK Indonesia dan PT. Asuransi ALLIANZ Indonesia", Diponegoro Law Journal, Vol 6, No. 2, 2017.

Sastradinata, Dhevi Nayasari, "Aspek Pertanggungjawaban Pengemudi Ojek Online Dalam Kasus Kecelakaan Yang Melibatkan Penumpang Dilihat Dari Hukum Perlindungan Konsumen", Jurnal Independent, Vol. 6, No. 2, Tahun 2018.

Siregar, Muchtaruddin, "Perlindungan Hukum Terhadap Data Pribadi Pengguna Jasa Transportasi Online Dari Tindakan Penyalahgunaan Pihak Penyedia Jasa Berdasarkan Undang-Undang Nomor 8 Tahun 1999 Tentang Perlindungan Konsumen", Diponegoro Law Journal, Vol. 5, No. 3, Tahun 2016.

Sulistiowati, "Pengaturan Asuransi Kecelakaan Jalan dalam Undang-Undang Nomor 22 Tahun 2009", Jurnal Mimbar Hukum, Vol. 23, No. 3, Tahun 2013.

Vikaliana, Resista, "Faktor-faktor Risiko dalam Perusahaan Jasa Pengiriman", Jurnal Logistik Indonesia, Vol. 1, No. 1, April 2017.

Yunita, Hilda, "Karakteristik Hubungan Hukum Dalam Asuransi Jasa Raharja Terhadap Klaim Korban Kecelakaan Angkutan Umum", Yuridika, Vol. 30 No. 3, tahun 2015.

Yuniza, Mailinda Eka, "Perbandingan Undang-Undang Nomor 14 Tahun 1992 Tentang Lalu Lintas Dan Angkutan Jalan Dengan Rancangan UndangUndang Republik Indonesia Tentang Lalu Lintas Dan Angkutan Jalan", Mimbar Hukum, Vol.21, No.2, Juni, 2009.

Zuhairi, Ahmad, "Konstruksi Perlindungan Hukum Bagi Pengadu/ Pelapor Kerugian Konsumen Dari Tuntutan Pencemaran Nama Baik Oleh Pelaku Usaha/Produsen", Jurnal Ius Kajian Hukum dan Keadilan, Vol. 3, No. 7, April 2015.

\section{Internet}

Badan Pengembangan dan Pembinaan Bahasa Kementerian Pendidikan dan Kebudayaan Republik Indonesia, "Asuransi https://kbbi.kemdikbud.go.id/entri/asuransi, diakses pada tanggal 25 September 2019.

Badan Pusat Statistik, Statistik Indonesia 2017, Indonesia: Badan Pusat Statistik.

Pan Pacific, "Pengertian Asuransi dan Risiko" http://panfic.com/id/insurance knowledge/pengertianasuransi-dan-risiko/, diakses tanggal 25 September 2019.

Axa Mandiri, "Asuransi Kecelakaan Diri", https://www.axa-mandiri. co.id/produk/asuransikecelakaan-diri-2/, tanggal 18 September 2019.

Jasa Raharja, “Lingkup Jaminan”, https://www.jasaraharja.co.id/layanan/ lingkup-jaminan, diakses pada tanggal 25 September 2019. 
Go-Ride, "Ketahui Informasi Lengkap Asuransi Kecelakaan Go-Ride", https://www.gojek.com/blog/asuransi/, diakses pada tanggal 18 September 2019.

Korlantas Polri, "Statistik Laka", http://korlantas.polri.go.id/statistik-2/, diunduh 1 Januari 2020.

M. Nurfaik, "Kontroversi Penggunaan Sepeda Motor Sebagai Angkutan Umum", https://rechtsvinding.bphn.go.id/jurnal_online/Naskah\%20Pak\%20Nur faik\%20Fix.pdf, diakses pada tanggal 25 September 2019.

Revisi UU LLAJ Lebih Praktis Ketimbang Membuat UU Baru", http://www.hukumonline.com/berita/baca/lt58f2d763e1edb/revisi-uullaj-lebih-praktis-ketimbang-membuat-uu-baru, diakses 30 Desember 2019.

Tribun Jakarta, "Menhub Sebut Angka Kecelakaan Sepeda Motor di Indonesia Capai 73 Persen", https://jakarta.tribunnews.com/2019/01/06/menhubsebut-angka-kecelakaan-sepeda-motor-di-indonesia-capai-73-persen, diakses pada 10 Januari 2019.

\section{Peraturan Perundang-Undangan}

Kitab Undang-Undang Hukum Dagang

Undang-Undang Nomor 40 Tahun 2014 Tentang Perasuransian, Lembaran Negara Republik Indonesia Tahun 2014 Nomor 337, Tambahan Lembaran Negara Republik Indonesia Nomor 5618.

Undang-Undang Nomor 33 Tahun 1964 Tentang Dana Pertanggungan Wajib Kecelakaan Penumpang, Lembaran Negara Republik Indonesia Tahun 1964 Nomor 137, Tambahan Lembaran Negara Republik Indonesia Nomor 2720.

Undang-Undang Nomor 34 Tahun 1964 Tentang Dana Kecelakaan Lalu Lintas Jalan, Lembaran Negara Republik Indonesia Tahun 1964 Nomor 138, Tambahan Lembaran Negara Republik Indonesia Nomor 2721.

Undang-Undang Nomor 22 Tahun 2009 Tentang Lalu Lintas dan Angkutan Jalan, Lembaran Negara Republik Indonesia Tahun 2009 Nomor 96, Tambahan Lembaran Negara Republik Indonesia Nomor 5025.

Peraturan Pemerintah Republik Indonesia Nomor 74 Tahun 2014 tentang Angkutan Jalan, Lembaran Negara Republik Indonesia Tahun 2014 Nomor 260, Tambahan Lembaran Negara Republik Indonesia Nomor 5594. 